\title{
Soil aggregate stability under different rain conditions for three vegetation types on the Loess Plateau (China)
}

\author{
Quanchao Zeng ${ }^{\mathrm{a}, \mathrm{b}}$, Frédéric Darboux ${ }^{\mathrm{c}}$, Cheng Man ${ }^{\mathrm{a}}$, Zhaolong Zhu ${ }^{\mathrm{a}}$, Shaoshan $\mathrm{An}^{\mathrm{a}, *}$

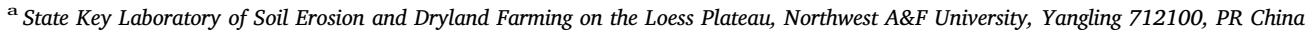 \\ ${ }^{\mathrm{b}}$ College of Resources and Environment, Huazhong Agricultural University, Wuhan 430070, PR China \\ ${ }^{\mathrm{c}}$ INRA, UR0272, UR Science du sol, Centre de recherche d'Orléans, CS 40001, F-45075 Orléans Cedex 2, France
}

\begin{abstract}
Soil aggregate stability is essential for moderating the soil quality and preventing soil erosion. Vegetation restoration may effectively increase the stability of soil aggregates via soil organic matter. This study was designed to investigate the effects of vegetation types with long-term revegetation on the soil aggregate characteristics. Three vegetation type zones (grass land, forest-grass land and forest land) were selected in the Yanhe Watershed (northwest China) as the subjects. Soil aggregate stability was determined by the method of Le Bissonnais, including three disruptive tests: fast wetting (FW), slow wetting (SW) and mechanical breakdown (WS). The results showed that the mean weighted diameter (MWD) significantly differed from the tests and vegetation types. In the 0-10 cm soil layer, MWD ranged from 2.65 to $3.26 \mathrm{~mm}$ for the SW test, which corresponded to very stable soil aggregate; they ranged from 0.53 to $1.08 \mathrm{~mm}$ for the WS test, and from 0.57 to $1.96 \mathrm{~mm}$ for the FW test, both of which corresponded to very unstable soil aggregates. In the 10-20 cm soil layer, MWD ranged from 2.75 to $3.33 \mathrm{~mm}$ for the SW test, 0.39 to $0.83 \mathrm{~mm}$ for the WS test, and 0.44 to $1.37 \mathrm{~mm}$ for the FW test. The MWDs under the three tests were the lowest for the grass land at both soil layers, and the MWDs for the WS and FW tests were significantly lower than the MWD for the SW test. In all three tests, MWDs showed the same order: forest land $>$ forest-grass land $>$ grass land. MWD indicated that forest land had much stronger ability to resist soil erosion no matter the rain conditions. The correlations between soil organic matter content and MWD for the FW and WS tests were significant $(\mathrm{P}<0.05)$. These results demonstrated that vegetation types had significant effects on the soil aggregates under the different rain conditions, and the soil organic matter and clay contents were significantly related to the soil aggregate stability. These results will guide the practice of reducing soil erosion for the different conditions and different vegetation types.
\end{abstract}

\section{Introduction}

Soil aggregate stability, an ability to resist breakdown by external forces, influences several soil physical or chemical processes, such as soil nutrient storage, water infiltration and the ability to resist soil erosion (Barthes and Roose, 2002). Specifically, aggregate stability affected the movement and storage of water in soils, soil aeration, soil erosion, biological activity, and crop growth (Zhang and Miller, 1996). Aggregate stability is a key factor in questions of soil fertility and environmental problems. Enhancing soil aggregate stability is an effective way to increase soil quality and prevent soil erosion and other environmental problems caused by soil degradation (Hortensius and Welling, 1996; Six et al., 2000; Zhu et al., 2017).

Human activity has had large impacts on the ecosystems of the world, especially in the Loess Plateau, China. Human activity in the
Loess Plateau has had significant effects on the local environment via a variety of methods, such as over-grazing, the conversions from forest land or grass land into farm land and urbanization (Fu and Chen, 2000). These events have caused a lot of environmental problems, such as soil degradation, soil erosion, the serious decline of vegetation cover and the disbalance of ecosystems. To prevent further land degradation and recover the ecosystems and enhance the service function of the ecosystem, the Chinese government has launched a series of ecological projects. The 'Grain for Green' project was implemented to recover the degraded ecosystems in the Loess Plateau since the 1990s (Cao et al., 2009). In the Loess Plateau, soil water erosion is a major threat that seriously affects the processing and functioning of the ecosystem. Recently, vegetation restoration has been proven to be an effective measure for the sustainable development of terrestrial ecosystems (Lï et al., 2012; Zeng et al., 2017). According to previous studies, soil water-

\footnotetext{
* Corresponding author.

E-mail address: shan@ms.iswc.ac.cn (S. An).
} 
stable aggregation can sensitively reflect the ability to resist erosion with the process of vegetation restoration (Algayer et al., 2014; An et al., 2010, 2013b; Cheng et al., 2015; Zhao et al., 2013). The land type is an important factor affecting soil aggregates via the binding agents in soils, such as soil organic matter and fungal hyphae (Ayoubi et al., 2012; Khormali et al., 2009; Zhao et al., 2017). In the Loess Plateau, most of the results related to soil aggregate stability were obtained from the conventional wet sieving method (for example, An et al., 2013b; Xu et al., 2016; Yoder, 1936). The Le Bissonnais' method, a new standard (ISO/DIS 10930, 2012), involves several mechanisms of soil aggregate breakdown (Le Bissonnais, 1996), including fast wetting (FW), slow wetting (SW) and mechanical breakdown (WS). This method can separate the mechanisms (such as slaking and differential clay swelling) and provide more information regarding soil aggregation, which has only recently begun to be applied to the Loess Plateau. For example, An et al. (2013b) reported that the Le Bissonnais method could well evaluate the stability of forest soil aggregate in the Loess Plateau (An et al., 2013b). However, few studies are available regarding the evolution of soil aggregate stability during revegetation on a large scale with different vegetation ecosystems in the Yanhe Watershed using different tests of the Le Bissonnais method. The three tests of the Le Bissonnais method represent different rain conditions (heavy storm rain, gentle rain and disturbance by external force), so it is well worth providing more specific information in order to understand the effects of vegetation types on soil aggregates.

The Yanhe Watershed is one of the most important tributaries of the Yellow River, which has great importance for the Loess Plateau. It is also an ideal research area. As the precipitation is unevenly distributed throughout the year, most occurred during the growing seasons (from June to September). Therefore, this research was conducted in this area with three selected different vegetation areas representing different land use types, including forest land, grass land and forest-grass land. The objectives of this study were to evaluate the characteristics of soil aggregate stability in different vegetation zones under different rain conditions in the Yanhe Watershed. We addressed the hypothesis that (1) forest land had the highest ability of soil aggregates for the three tests due to its higher soil organic matter; and (2) the difference in the aggregate stability differed from the diverse land uses and unique tests, which represented distinctive rain conditions. This finding will promote the understanding of the effects of revegetation on soil quality and will help guide the practice and management of enhancing soil aggregate stability.

\section{Materials and methods}

\subsection{Experimental site}

The study sites were conducted in three small watersheds, including the Dongzigou watershed (DW) $\left(109^{\circ} 15^{\prime} 33^{\prime \prime}-109^{\circ} 17^{\prime} 42^{\prime \prime} \mathrm{E}\right.$, $36^{\circ} 55^{\prime} 50^{\prime \prime}-36^{\circ} 57^{\prime} 46^{\prime \prime} \mathrm{N}$ ), the Xiaohegou watershed (ZW) $\left(109^{\circ} 11^{\prime} 58^{\prime \prime}-109^{\circ} 14^{\prime} 39^{\prime \prime} \mathrm{E}, 36^{\circ} 59^{\prime} 33^{\prime \prime}-37^{\circ} 2^{\prime} 40^{\prime \prime} \mathrm{N}\right)$ and the Gaojiagou watershed (GW) $\left(108^{\circ} 58^{\prime} 5^{\prime \prime}-109^{\circ} 2^{\prime} 52^{\prime \prime} \mathrm{E}, 37^{\circ} 12^{\prime} 31^{\prime \prime}-37^{\circ} 16^{\prime} 36^{\prime \prime} \mathrm{N}\right)$, located in the Yanhe River Basin, northern Shaanxi Province, China (Fig. 1). The Dongzigou watershed mainly consists of trees and grasses, a typical forest vegetation land. The Xiaohegou watershed consists of shrubs and grasses, a typical forest-grass vegetation land. The Gaojiagou watershed consists of grasslands, a typical grass vegetation land. The soil type is loess, according to the Genetic Soil Classification of China (Zeng et al., 2016), or entisol, according to the USA taxonomy (Soil Survey Staff, 1999). The climate is characterized by cold dry winters and warm moist summers. The mean annual precipitation is approximately 400 to $500 \mathrm{~mm}$, mostly occurring in a few heavy storms during the summer (Wang et al., 2014). The mean annual temperature ranged from $7.8^{\circ} \mathrm{C}$ to $10.7^{\circ} \mathrm{C}$.

\subsection{Soil sampling}

Soil samples were collected from 0 to $10 \mathrm{~cm}$ and 10 to $20 \mathrm{~cm}$ depths in June 2013. In each land use, we selected 8-13 sample sites that have similar terrain (slope position and aspect) and similar plant communities. The plants and environments are described in Table 1 . In every sample site, three $20 \mathrm{~m} \times 20 \mathrm{~m}$ subplots were selected for sampling. Two types of samples were collected in each subplot for the analysis of soil properties and soil aggregates. Firstly, seven core samples were taken from each plot and mixed to form a composite sample. The fresh samples were sealed in plastic bags and transported to the laboratory for analyses of the chemical and physical properties. Secondly, large roots, stones and macro fauna were removed from the soil samples. These samples were used for the measurement of basic soil properties, including $\mathrm{pH}$, soil organic matter (SOM), total nitrogen (TN), total $\mathrm{P}$ (TP) and dissolved organic phosphorus (DOP). Soil particles were classified into 3 size fractions (Table 2): clay $(<0.002 \mathrm{~mm})$, silt (2-0.05 mm), sand (0.05-2 mm) (Liu et al., 2005).

Additionally, undisturbed soil samples were taken for the aggregate stability analysis from each plot with three replicates in the subplots, sealed and transported to the laboratory, where they were air dried at room temperature $\left(20^{\circ} \mathrm{C}\right)$. Each soil sample was sieved at $3-5 \mathrm{~mm}$ to generate aggregates for the stability tests by the method described by Le Bissonnais (1996).

\subsection{Analysis of soil physical and chemical properties}

Soil $\mathrm{pH}$ was determined with a $\mathrm{pH}$ electrode, extracted from $0.01 \mathrm{M}$ $\mathrm{CaCl}_{2}$ with a ratio of 1:2.5 (Bao, 2000; Huang et al., 2015). The bulk density (BD) was determined using a stainless steel cutting ring method $\left(100 \mathrm{~cm}^{3}\right)$ to collect the undisturbed soils at different soil layers (Huang et al., 2015). Soil organic matter (SOM) was determined by wet digestion with a mixture of $5 \mathrm{~mL}$ of $0.8 \mathrm{~mol} / \mathrm{L}$ potassium dichromate $\left(\mathrm{K}_{2} \mathrm{Cr}_{2} \mathrm{O}_{7}\right)$ and $5 \mathrm{~mL}$ of concentrated sulfuric acid $\left(\mathrm{H}_{2} \mathrm{SO}_{4}\right)$ (Kalembasa and Jenkinson, 1973), and the total $\mathrm{N}$ was measured by the Kjeldahl method (Sparks et al., 1996). Soil total P (TP) was determined by colorimetric analysis (UV 2800) with a spectrophotometer after wet digestion with $\mathrm{H}_{2} \mathrm{SO}_{4}-\mathrm{HClO}_{4}$ (Nelson and Sommers, 1982). Soil particle size distributions were measured by laser diffraction (Mastersizer 2000, Malvern Instruments, Malvern, England), including clay, silt and sand content (USDA taxonomy) (Liu et al., 2005).

\subsection{Aggregate stability measurements}

Aggregate stability was determined using the method described by Le Bissonnais (1996). This method included three disruptive tests that correspond to various wetting conditions and energies: fast wetting (FW), slow wetting (SW) and mechanical breakdown (WS). Before testing, the $3-5 \mathrm{~mm}$ aggregate samples need be dried at $40^{\circ} \mathrm{C}$ for $24 \mathrm{~h}$ to a constant weight. Three replicates were conducted for each test. After each test, the fragmented samples were collected and dried at $40{ }^{\circ} \mathrm{C}$ for $>48 \mathrm{~h}$ to a consistent weight and gently sieved using a column of six sieves: $2,1,0.5,0.2,0.1$ and $0.05 \mathrm{~mm}$. The mass of each size aggregate was weighed and calculated. Finally, the mean weighted diameter (MWD) was calculated using the following equation (Oguike and Mbagwu, 2009). Five classes of the soil aggregate stability were identified according to the values of MWD (Table 3).

$\mathrm{MWD}=\sum_{i}^{\mathrm{n}} \chi_{i} \omega_{i} / \sum_{i}^{n} \omega_{i}$

where $\omega_{i}$ is the proportion of aggregates in the size class $i$, and $\chi_{i}$ is the mean diameter of each size class. 


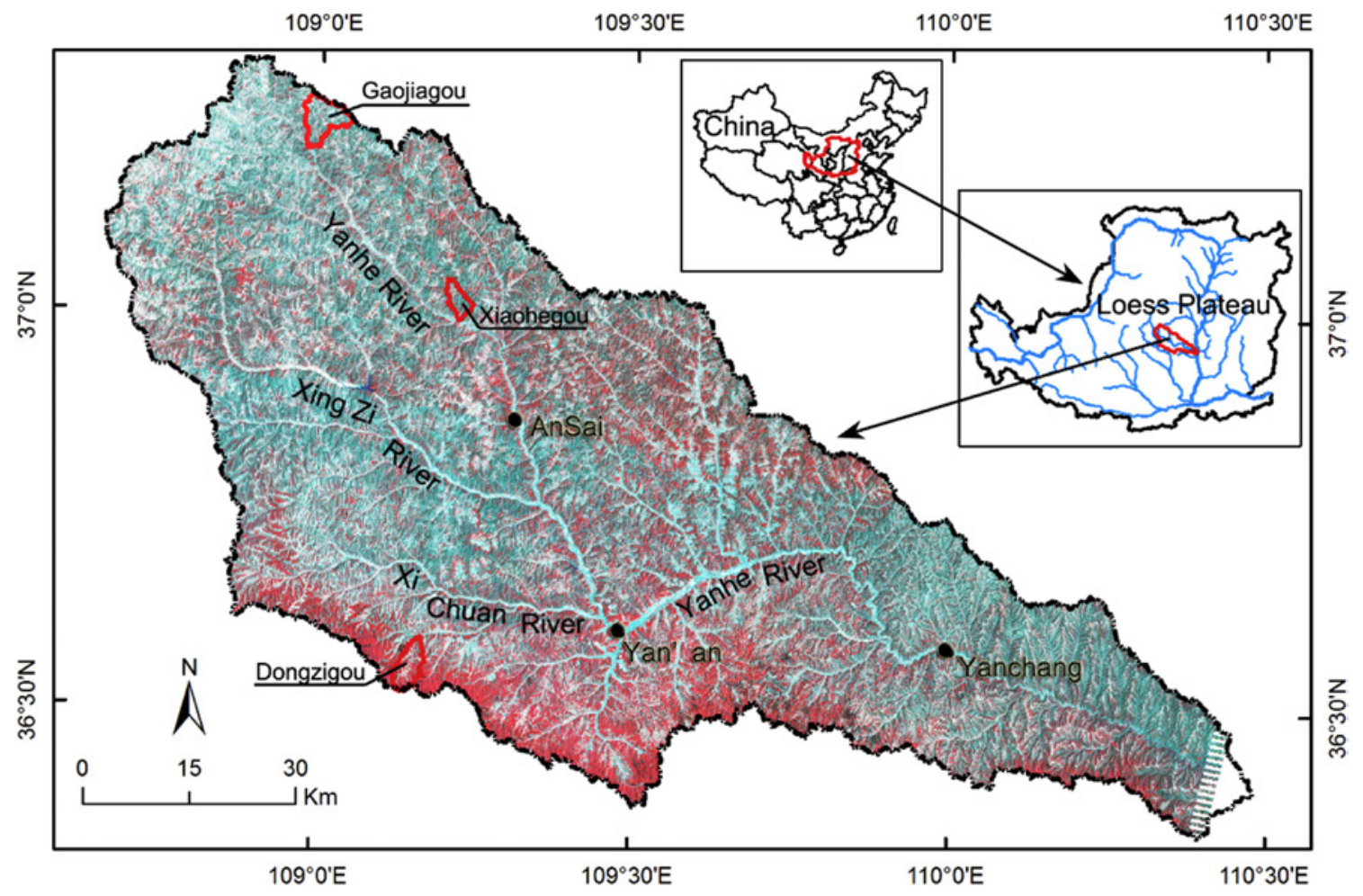

Fig. 1. The location of the sampling sites.

Table 1

The descriptions of soil sample sites.

\begin{tabular}{|c|c|c|c|}
\hline Watershed & Sample site number & Height $(\mathrm{m})$ & Predominant species \\
\hline \multirow[t]{8}{*}{ Dongzigou watershed: forest zones } & 1 & 1372 & Robinia pseudoacacia, Sophora moorcroftiana, Artemisia sacrorum \\
\hline & 2 & 1351 & Artemisia sacrorum \\
\hline & 3 & 1284 & Syzygiumaromaticum, Ostryopsisdavidiana, Rosa xanthine, Artemisiagiraldii, Artemisia sacrorum \\
\hline & 4 & 1346 & Sophora moorcroftiana, Bothriochloa ischcemum, Lespedeza davurica \\
\hline & 5 & 1301 & Platycladus orientalis, Abelia biflora, Syzygium aromaticum, Carex lancifolia \\
\hline & 6 & 1259 & Quercus wutaishanica, Spiraea pubescens, Syzygium aromaticum, Lespedeza floribunda, Carex lancifolia \\
\hline & 7 & 1334 & Acer buergerianum, Rosa xanthina, Carex lancifolia \\
\hline & 8 & 1348 & Artemisia sacrorum, Artemisia giraldii \\
\hline \multirow[t]{13}{*}{ Xiaohegou watershed: forest-grass zones } & 1 & 1380 & Artemisia sacrorum \\
\hline & 2 & 1355 & Bothriochloaischcemum, Artemisia sacrorum, Lespedeza davurica \\
\hline & 3 & 1356 & Artemisia sacrorum \\
\hline & 4 & 1349 & Bothriochloaischcemum, Lespedeza davurica, Artemisia sacrorum \\
\hline & 5 & 1338 & Bothriochloaischcemum, Artemisia sacrorum \\
\hline & 6 & 1345 & Bothriochloaischcemum, Artemisia sacrorum, Artemisia giraldii \\
\hline & 7 & 1307 & Bothriochloaischcemum, Lespedeza davurica, Artemisia giraldii, Artemisia sacrorum \\
\hline & 8 & 1307 & Bothriochloaischcemum, Artemisia giraldii \\
\hline & 9 & 1265 & Artemisia sacrorum, Bothriochloaischcemum, Artemisia giraldii \\
\hline & 10 & 1315 & Artemisia sacrorum, Artemisia giraldii \\
\hline & 11 & 1315 & Artemisia sacrorum \\
\hline & 12 & 1312 & Artemisia sacrorum, Thymus mongolicus \\
\hline & 13 & 1309 & Artemisia giraldii, Artemisia sacrorum \\
\hline \multirow[t]{11}{*}{ Gaojiagou watershed: grass zones } & 1 & 1334 & Thymus mongolicus \\
\hline & 2 & 1347 & Stipa grandis, Lespedeza davurica \\
\hline & 3 & 1370 & Lespedeza davurica, Poasphondylodes, Artemisia sacrorum \\
\hline & 4 & 1285 & Artemisia sacrorum \\
\hline & 5 & 1321 & Artemisia sacrorum, Artemisia giraldii, Artemisia frigida, Lespedeza davurica \\
\hline & 6 & 1270 & Lespedeza davurica, Artemisia giraldii \\
\hline & 7 & 1304 & Artemisia sacrorum, Artemisia giraldii \\
\hline & 8 & 1312 & Artemisia sacrorum \\
\hline & 9 & 1337 & Poa sphondylodes, Phragmites australis, Artemisia sacrorum \\
\hline & 10 & 1345 & Artemisia sacrorum \\
\hline & 11 & 1379 & Artemisia giraldii \\
\hline
\end{tabular}

\subsection{Data analysis}

An analysis of variance (ANOVA) was performed to compare the differences between diverse vegetation types, and the Scheffe's test was used for multiple comparisons. The correlations between the soil aggregate MWD and the soil properties studied were calculated, and the Pearson correlation test was carried out. All statistical analyses were carried out with SPSS 18.0 (SPSS, Inc., Chicago, IL, USA). The 
Table 2

The soil proportions of clay, silt and sand in the different land uses.

\begin{tabular}{|c|c|c|c|}
\hline Land use & $\begin{array}{l}\text { Clay }(<0.002 \mathrm{~mm}) \\
\%\end{array}$ & $\begin{array}{l}\text { Silt }(0.002-0.02 \mathrm{~mm}) \\
\%\end{array}$ & $\begin{array}{l}\text { Sand }(0.02-2 \mathrm{~mm}) \\
\%\end{array}$ \\
\hline Forest land & $10.56 \pm 2.54 a$ & $15.66 \pm 2.97 a$ & $73.78 \pm 5.49 b$ \\
\hline $\begin{array}{l}\text { Forest- } \\
\text { grass } \\
\text { land }\end{array}$ & $6.58 \pm 0.59 b$ & $10.33 \pm 1.09 b$ & $83.07 \pm 1.63 a$ \\
\hline Grass land & $6.92 \pm 0.95 b$ & $10.79 \pm 1.73 b$ & $82.40 \pm 2.53 a$ \\
\hline
\end{tabular}

Note: Different lowercase letters indicate significant differences under different land uses at the level of 0.05 .

Table 3

The classes of soil aggregate stability based on the values of MWD (Le Bissonnais, 1996).

\begin{tabular}{lcl}
\hline Class & MWD/mm & Stability \\
\hline 1 & $<0.4$ & Very unstable \\
2 & $0.4-0.8$ & Unstable \\
3 & $0.8-1.3$ & Medium \\
4 & $1.3-2.0$ & Stable \\
5 & $>2.0$ & Very stable \\
\hline
\end{tabular}

significance was set at the 0.05 level. The figures were created with Origin Pro 2016 (OriginLab Corporation, Northampton, MA, USA).

\section{Results}

\subsection{The chemical and biochemical characteristics of the soil samples from} different vegetation lands

Table 4 demonstrates the soil properties for the three vegetation land types. The land types exhibited significant differences in soil properties $(\mathrm{P}<0.05)$. The SOM contents ranged from 8.97 to $33.72 \mathrm{~g} \cdot \mathrm{kg}^{-1}$ in the $0-10 \mathrm{~cm}$ soil layer. The highest value for SOM was observed in the forest land, and the lowest one was observed in the grass land. A similar trend presented for the soil TN. The highest values for soil $\mathrm{BD}$ and soil $\mathrm{pH}$ were found in the grass land, and the lowest ones were observed in the forest land. The land types had no significant influence on the soil TP contents with the range from 0.58 to $0.68 \mathrm{~g} / \mathrm{kg}$. Soil dissolved organic phosphorus (DOP) ranged from 9.21 to $24.49 \mathrm{mg} / \mathrm{kg}$ in the $0-10 \mathrm{~cm}$ soil layer depth and from 3.63 to $10.34 \mathrm{mg} / \mathrm{kg}$ in the $10-20 \mathrm{~cm}$ soil layer depth. Forest soils had the highest soil DOP content in both soil layers.

\subsection{Aggregate distribution in the different tests}

The soil aggregate distributions using three tests in the different vegetation land types are shown in Fig. 2. The size of the main fraction was $>2 \mathrm{~mm}$ for the slow wetting test (SW) in the three vegetation lands. This size fraction accounted for $72 \%$ to $91 \%$ of the total soil weight. The lowest value for the size $>2 \mathrm{~mm}$ was found in the grass land, and the highest value was observed in the forest land.
For the fast wetting (FW) test, $50 \%$ or more of forest-grass land and grass land soil fragments was $<0.2 \mathrm{~mm}$ (Fig. 3). Compared to forestgrass and grass land, the size $>2 \mathrm{~mm}$ for the FW test was much higher in the forest land $(48 \%$ in the $0-10 \mathrm{~cm}$ depth; $30 \%$ in the $10-20 \mathrm{~cm}$ depth). The aggregate distributions for the WS test showed a similar trend with that determined by the FW test. In the forest land, the size $<0.2 \mathrm{~mm}$ for the WS test ranged from $36 \%$ to $42 \%$ for the $0-10 \mathrm{~cm}$ soil layer and $23 \%$ to $29 \%$ for the $10-20 \mathrm{~cm}$ soil layer. In both soil depth ranges, the percentage of $<0.2 \mathrm{~mm}$ aggregates for the three tests increased in the following order: grass land $<$ forest-grass land $<$ forest land.

The results of soil MWD revealed that vegetation types had a significant effect on the soil MWD (Fig. 4). In the $0-10 \mathrm{~cm}$ soil layer, the MWD for the SW test ranged from 2.65 to $3.26 \mathrm{~mm}$, which corresponded to very stable soil aggregates, while MWD for the WS test ranged from 0.53 to $1.08 \mathrm{~mm}$, and MWD for the FW test ranged from 0.57 to $1.96 \mathrm{~mm}$. For the WS and FW tests, grass and forest-grass soils corresponded to very unstable soil aggregates (Le Bissonnais, 1996). In the $10-20 \mathrm{~cm}$ soil layer, the MWD for the SW test ranged from 2.75 to $3.33 \mathrm{~mm}$, MWD for the WS test ranged from 0.39 to $0.83 \mathrm{~mm}$, and MWD for the FW test ranged from 0.44 to $1.37 \mathrm{~mm}$. The MWDs for the SW, WS and FW tests were the lowest for grass land in both soil layers.

\subsection{Relationships between soil physicochemical properties within aggregates}

In the present study, for the SW test, the correlations between the soil properties and MWD were not significant; the MWD in the WS and FW tests had significant positive correlations with SOM $(r=0.582$ for WS test; $r=0.491$ for FW test), clay content ( $r=0.577$ for WS test; $r=0.550$ for FW test) and silt content $(r=0.565$ for WS test; $r=0.554$ for FW test) (Table 5). For the WS and FW tests, soil sand content had significant correlations with MWD $(r=-0.577$ for WS test; $r=-0.558$ for $\mathrm{FW}$ test).

\section{Discussion}

\subsection{Effect of land use and vegetation types on soil aggregates}

Vegetation restoration has proven to be an effective way to improve soil quality and the resistance to soil erosion. In this study, long-term revegetation significantly affected the soil physicochemical properties studied and soil aggregate stability. These results were in agreement with other reports about revegetation in the Loess Plateau (An et al., 2013b; Deng et al., 2014; Zeng et al., 2016). In general, there are many factors that affect soil aggregate stability, including intrinsic and external factors (Amezketa, 1999). The intrinsic factors are linked to primary soil properties such as soil clay content, organic matter content and soil minerals, whereas the external factors consist of climatic variables (e.g., mean annual precipitation and mean annual temperature), vegetation types (e.g., forest land, grass land and crop land) and agricultural practices such as tillage, irrigation and fertilizer applications (Annabi et al., 2011). In the natural environment (this studied areas), there was no soil disturbance or management during the process

Table 4

Soil properties of different vegetation systems $(0-10 \mathrm{~cm}$ and $10-20 \mathrm{~cm})$; means \pm S.E.

\begin{tabular}{|c|c|c|c|c|c|c|c|}
\hline Land use & Soil layer & $\mathrm{BD}\left(\mathrm{g} / \mathrm{cm}^{3}\right)$ & $\mathrm{pH}$ & SOM (g/kg) & $\mathrm{TN}(\mathrm{g} / \mathrm{kg})$ & $\mathrm{TP}(\mathrm{g} / \mathrm{kg})$ & DOP (mg/kg) \\
\hline Forest land & $0-10 \mathrm{~cm}$ & $1.01 \pm 0.13 b$ & $8.57 \pm 0.23 b$ & $33.72 \pm 24.60 \mathrm{a}$ & $1.61 \pm 1.13 \mathrm{a}$ & $0.68 \pm 0.07 a$ & $24.49 \pm 18.86 a$ \\
\hline Forest-grass land & $0-10 \mathrm{~cm}$ & $1.18 \pm 0.07 a$ & $8.97 \pm 0.07 a$ & $8.97 \pm 2.74 b$ & $0.58 \pm 0.20 b$ & $0.58 \pm 0.03 b$ & $9.21 \pm 5.07 b$ \\
\hline Grass land & $0-10 \mathrm{~cm}$ & $1.11 \pm 0.05 \mathrm{a}$ & $8.89 \pm 0.16 a$ & $8.96 \pm 3.37 b$ & $0.56 \pm 0.19 b$ & $0.58 \pm 0.04 b$ & $13.12 \pm 4.32 \mathrm{ab}$ \\
\hline Forest land & $10-20 \mathrm{~cm}$ & $1.07 \pm 0.12 b$ & $8.70 \pm 0.13 b$ & $18.6 \pm 11.14 \mathrm{a}$ & $0.95 \pm 0.58 \mathrm{a}$ & $0.63 \pm 0.04 a$ & $10.34 \pm 8.00 \mathrm{a}$ \\
\hline Forest-grass land & $10-20 \mathrm{~cm}$ & $1.21 \pm 0.07 \mathrm{a}$ & $9.00 \pm 0.09 b$ & $7.23 \pm 2.73 b$ & $0.42 \pm 0.16 b$ & $0.56 \pm 0.02 b$ & $3.63 \pm 1.52 b$ \\
\hline Grass land & $10-20 \mathrm{~cm}$ & $1.20 \pm 0.05 a$ & $8.94 \pm 0.14 b$ & $7.27 \pm 2.58 \mathrm{~b}$ & $0.42 \pm 0.15 b$ & $0.57 \pm 0.03 b$ & $4.00 \pm 1.66 \mathrm{~b}$ \\
\hline
\end{tabular}

Note: BD, bulk density; SOM, soil organic matter; TN, total nitrogen; TP, total phosphorus; DOP, dissolved organic phosphorus. Different lowercase letters indicate significant differences under different land uses at the level of 0.05 . 

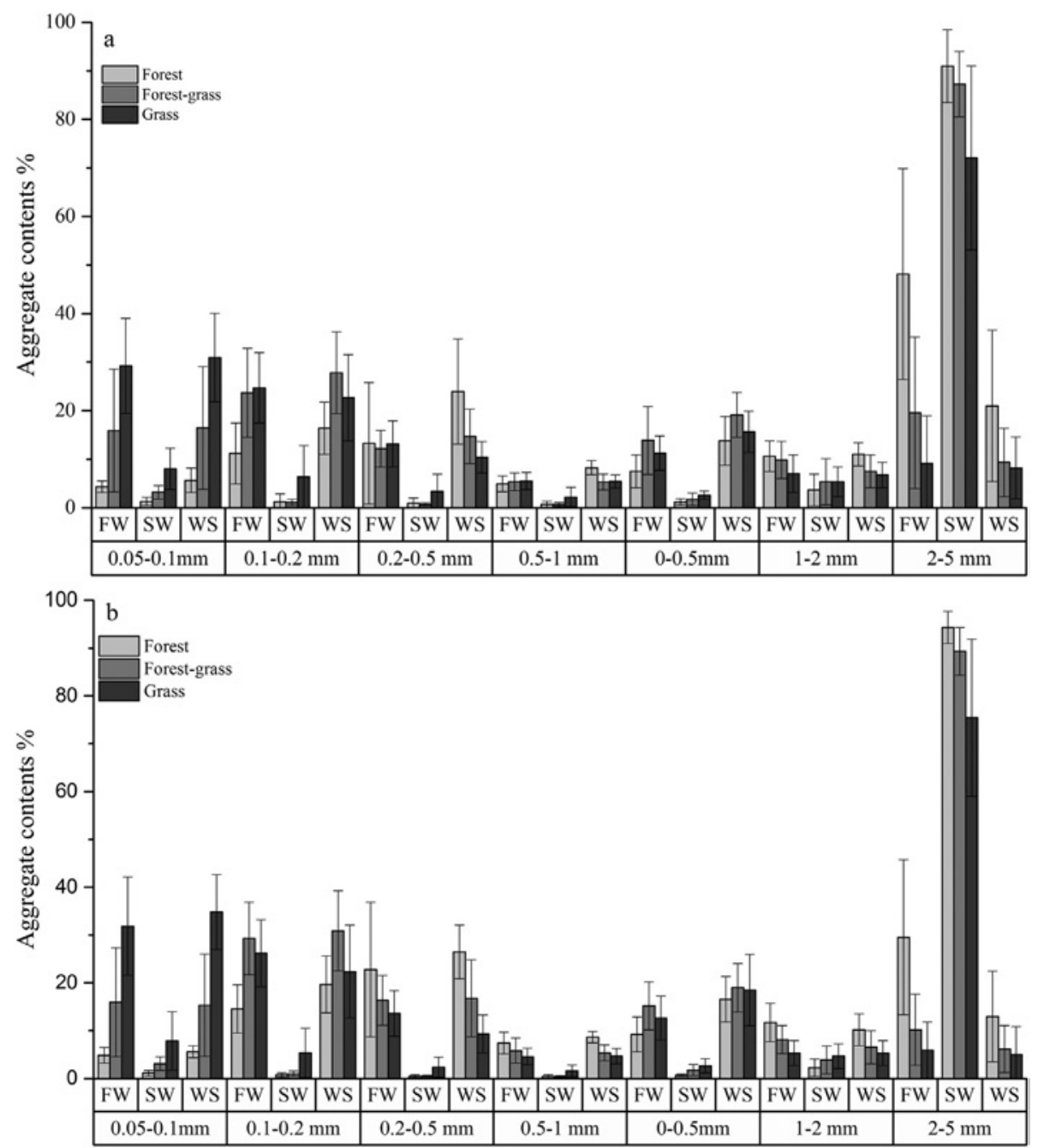

Fig. 2. Distribution of soil aggregate fractions resulting from the stability tests for the three vegetation systems. a: $0-10 \mathrm{~cm}$ soil layer; b: $10-20 \mathrm{~cm}$ soil layer. SW, slow wetting; FW, fast wetting; WS, mechanical breakdown.

of revegetation; therefore, vegetation types, climatic factors and soil properties were the main factors.

In this study, the soils in forest land had higher SOM, TN, TP and DOP than those in grass land and forest-grass land. The higher SOM and carbohydrate contents contribute to aggregate stabilization and formation through bridging between clay particles (Chaplot and Cooper, 2015). Le Bissonnais (1996) also found that forest soil aggregates had greater stability than a grass soil, which was consistent with this study. SOM acted as a binding agent during the aggregation process. Various organic fractions participate in aggregate stabilization, particularly fungi (Baldock, 2002). Meanwhile, forest land had higher levels of binding agents such as polysaccharides and fungi in the rhizosphere or SOM resulting from the increased quantity of litter. Furthermore, lignin and cellulose derived from plant litter can form organic cementing material to increase soil aggregate stability. Some researchers reported that plant community characteristics, such as plant diversity and the presence of grasses and legumes, significantly affected soil aggregate stability through changes in root biomass, soil organic carbon concentrations, soil microbial biomass and the biomass of earthworms (Pérès et al., 2013). Plant roots were another factor for the stabilization and formation of soil aggregates. Erktan et al. (2016) reported that a weak relation was observed between fine roots and soil aggregate stability. However, some studies showed that soil aggregate stability was positively correlated with fine roots (Gyssels et al., 2005; Miller and Jastrow, 1990). Fine roots enhanced the soil aggregate stability via the interaction with mycorrhizal fungal, which produced exudates and binding agents and promoted the formation of soil aggregates (Eisenhauer et al., 2011; Six et al., 2004).

Vegetation protects soil against erosion via several mechanisms, such as the reduction of splash, the increase in rain infiltration, or the promotion of soil cohesion due to root development (Greenway, 1987). On the Loess Plateau, there was serious soil erosion before vegetation restoration, but along with the increasing of plant cover, soil aggregate stability was increased gradually. This is due to the positive feedback of the vegetation on soil quality due to the organic matter contribution by means of the litter. Although this stability differed for different vegetation types, this was a useful and practical way to address the serious erosion problem, consistent with the results reported by previous studies on erosion of soil (An et al., 2013b; Erktan et al., 2016; Zhou et al., 2012).

\subsection{Relationships between soil characteristics and soil aggregate stability}

The results showed that SOM was significantly correlated with MWD for the WS and FW tests, with the highest Pearson Coefficient (Table 5). This was consistent with numerous previous studies in different areas (An et al., 2013b; Erktan et al., 2016; Le Bissonnais et al., 2007; Pérès et al., 2013; Six et al., 2004). Along with vegetation succession, Erktan et al. (2016) found that the soil organic carbon concentration held the most explanatory power for the soil aggregate 


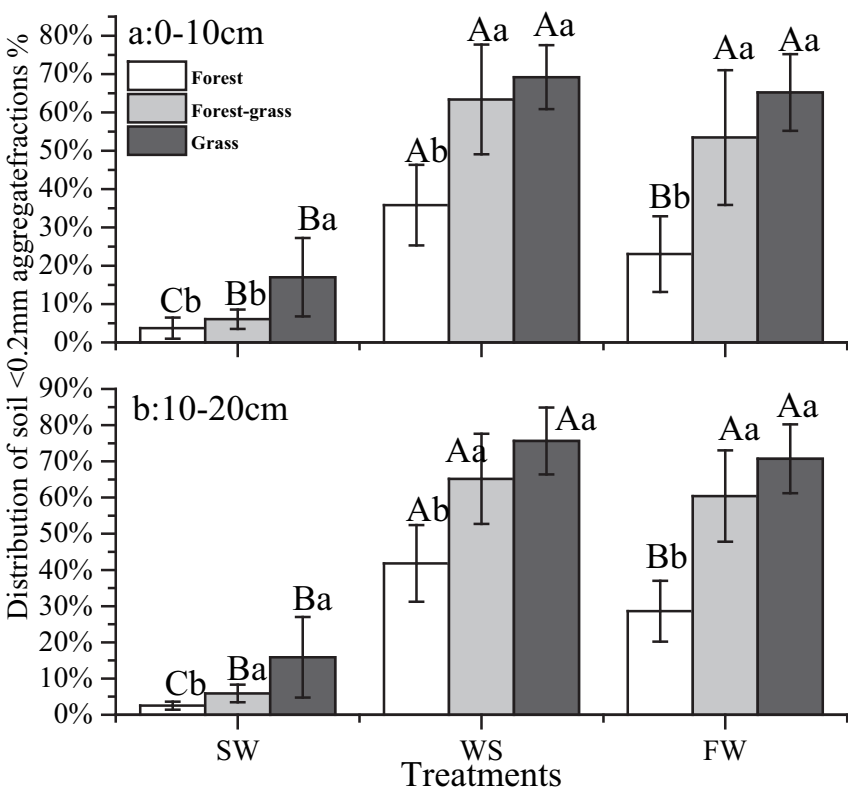

Fig. 3. Distribution of soil $<0.2 \mathrm{~mm}$ aggregate size fractions resulting from the stability tests for the three different vegetation systems. Different capital letters indicate significant differences under the different treatments (SW, slow wetting; FW, fast wetting; WS, mechanical breakdown); different lower case letters indicate significant differences under different vegetation types $(\mathrm{P}<0.05)$.

stability in the different vegetation type soils (Erktan et al., 2016). We also found that soil MWD significantly increased with the content of clay, which supported the theory that soil clay contents influence soil stability. Soil slaking degree was another characteristic affecting soil aggregate stability (Bissonnais and Arrouays, 1997). SOM compounds varied with the degree of soil slaking, with more easily decomposable compounds in grass land (Freschet et al., 2013) and more recalcitrant hydrophobic compounds in forest land (Abiven et al., 2007, 2009). Recalcitrant hydrophobic compounds played an important role in reducing soil aggregate wet-stability and enhancing stability against slaking (Le Bissonnais et al., 2007).

The soil particle size distributions showed that clay, silt and sand contents were significantly correlated with soil aggregate stability (Table 5). Previous studies indicated that soil particle size distribution had an underpinning role on maintaining soil aggregate stability (Erktan et al., 2016; Kiem and Kandeler, 1997; Six et al., 2004). This effect was stronger under lower SOC concentration soils $(<15 \mathrm{~g} / \mathrm{kg})$ (Le Bissonnais et al., 2007). Inconsistently with previous results (Erktan et al., 2016; Le Bissonnais et al., 2007; Six et al., 2004), silt content was positively related to soil aggregate stability. In the forest land that had
Table 5

Correlations between the soil MWD and soil properties.

\begin{tabular}{lllll}
\hline & SOM & Clay & Silt & Sand \\
\hline MWDsw & $0.182^{*}$ & 0.131 & 0.105 & -0.118 \\
MWDws & $0.582^{* *}$ & $0.577^{* *}$ & $0.565^{* *}$ & $-0.577^{* *}$ \\
MWDfw & $0.491^{* *}$ & $0.550^{* *}$ & $0.554^{* *}$ & $-0.558^{* *}$
\end{tabular}

Note: MWDsw, mean weighted diameter in the slow wetting test; MWDws, mean weighted diameter in the mechanical breakdown test; MWDfw, mean weighted diameter in the fast wetting test; SOM, soil organic matter.

* Indicates a significant difference at the level of 0.05 .

** Indicates a significant difference at the level of 0.01 .

higher contents of clay and silt, these particles enhanced soil aggregate stability via increased SOM and plant cover. In summary, sand contents had a negative effect on soil aggregates; however, silt and clay promoted the stability of soil aggregates.

\subsection{The difference in soil aggregate stability under different rain conditions}

Regardless of vegetation types, soil MWD in the SW test was significantly higher than that in other tests and was identified as "very stable" based on the classification of Le Bissonnais (Le Bissonnais, 1996). Slow wetting with controlled tension corresponds to a field condition of wetting under gentle rain (Le Bissonnais, 1996). Therefore, gentle rain was not the main factor breaking soil aggregates in the Loess Plateau. The values of MWD in the SW test were $>2$ for all land uses, with the highest ones observed in the forest land soil, which suggested that forest soil aggregates were the most stable in the gentle rain condition. Fast wetting represented the breakdown mechanism in the conditions of a heavy rain storm in summer (Le Bissonnais, 1996). The studied areas often experienced heavy rain storms, contributing approximately $70-80 \%$ of the annual precipitation (Jiao et al., 2012). Therefore, the stability of the soil aggregates in the heavy rain storm needs to be given more attention in the Loess Plateau. The results for the FW test showed that the mean MWD was $2.0 \mathrm{~mm}$ for the $0-10 \mathrm{~cm}$ soil layer and $1.4 \mathrm{~mm}$ for the $10-20 \mathrm{~cm}$ soil layer, suggesting that forest soils had higher stability in the condition of heavy rain storms, establishing that forest land was a perfect measure to protect soil aggregates. Across the classification of Le Bissonnais, MWD values in the fast wetting test indicated that the grass and forest-grass soil aggregates were unstable, especially in the $10-20 \mathrm{~cm}$ soil layer. These observations revealed that grass and forest-grass lands were more prone to erosion under heavy rain storms than forest land. Similar results were found in the soils (An et al., 2013a; Le Bissonnais, 1996). The plant coverage and the chemical protection can be used to explain this mechanism. Firstly, forest land had higher plant coverage that prevented the heavy rain from directly breaking down soil aggregates (Cerda, 1998; Pérès et al.,

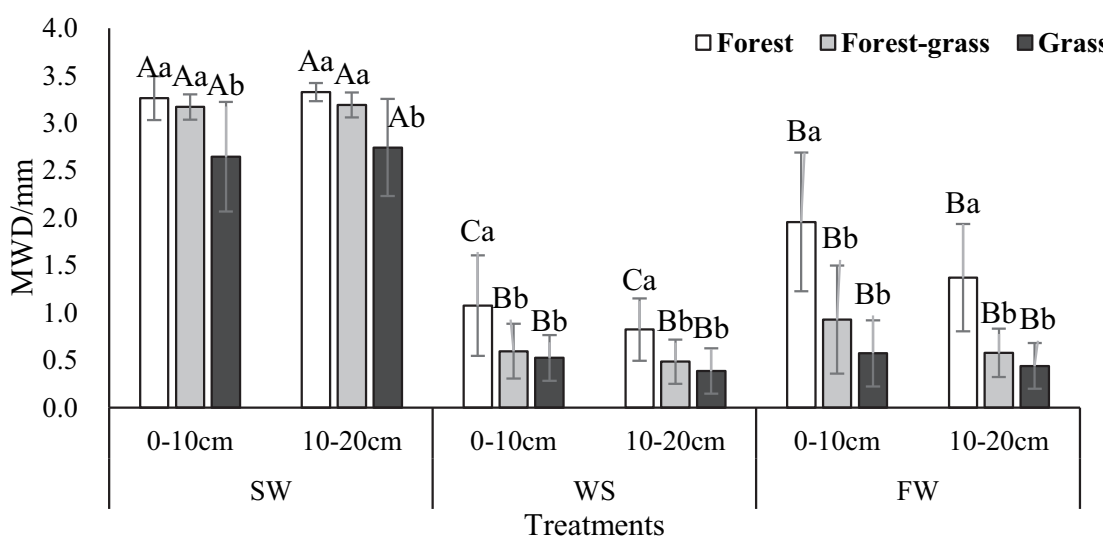

Fig. 4. The mean weight diameters (MWDs) of the three aggregate stability tests for the three vegetation types. Different capital letters indicate significant differences under the different treatments (SW, slow wetting; FW, fast wetting; WS, mechanical breakdown); different lower case letters indicate significant differences under different vegetation types $(\mathrm{P}<0.05)$. 
2013; Ruiz-Colmenero et al., 2013). Another mechanism was chemical protection via binding agents (Ayoubi et al., 2012). Forest soils had more binding agents such as soil organic matter, plant roots and fungal hyphae to protect soil aggregates (Ayoubi et al., 2012; Le Bissonnais, 1996).

Although the WS test represented the condition of mechanical breakdown by external force, it could provide a theoretical foundation for disturbed areas such as forest land that had been converted into farmland. The forest soil MWD in the WS test was significant higher than grass and forest-grass soils, indicating that forest soil aggregates had higher resistance to mechanical breakdown like soil tillage. Grass and forest-grass soil aggregates were unstable and easily broken by mechanical disturbance.

Overall, the fast wetting (FW) test of the Le Bissonnais method was a better way to evaluate the ability of soil aggregates in the Loess Plateau because of the high proportion of heavy storms, which accounted for $70 \%$ to $90 \%$ of the total annual rainfall. The stability of the soil aggregates in the forest land was higher than that with other land uses, whether it was in the conditions of gentle rain, heavy rain storm or disturbance by external force.

\section{Conclusion}

Soil aggregate stability is a promising indicator in degraded lands. Vegetation types had an important effect on the soil aggregate stabilization and formation. Under the three treatments, the MWD showed the same order of forest land $>$ forest-grass land $>$ grass land, suggesting that forest land soil aggregate was the most stable. SOM, a binding agent, was the key driver to influence the formation of soil aggregates, which was significantly correlated with MWD. Among the three tests, FW was the most favorable method for evaluating the soil aggregate stability due to the frequent occurrence of heavy rain storms in the Loess Plateau. Forest land had the greatest resistance to soil erosion and loss of soil nutrients, which would guide the practice of ecological construction in the Loess Plateau and other degraded areas. Grass and forest-grass land should be given much more attention in the management of soil erosion problems.

\section{Acknowledgments}

We thanked Dr. Wang Zhijie conducted the map figure. This study was supported by the National Natural Science Foundation of China (41671280 and 41771317), Special-Funds of Scientific Research Programs of State Key Laboratory of Soil Erosion and Dryland Farming on the Loess Plateau (A314021403-C6) and the Open Program of State Key Laboratory of Soil Erosion and Dryland Farming on the Loess Plateau, Institute of Soil and Water Conservation, CAS\&MWR (A314021402-1812). We also thanked the editor and the reviewers for giving us constructive suggestions.

\section{References}

Abiven, S., Menasseri, S., Angers, D., Leterme, P., 2007. Dynamics of aggregate stability and biological binding agents during decomposition of organic materials. Eur. J. Soil Sci. 58, 239-247.

Abiven, S., Menasseri, S., Chenu, C., 2009. The effects of organic inputs over time on soil aggregate stability-a literature analysis. Soil Biol. Biochem. 41, 1-12.

Algayer, B., et al., 2014. Aggregate stability of a crusted soil: differences between crust and sub-crust material, and consequences for interrill erodibility assessment. An example from the Loess Plateau of China. Eur. J. Soil Sci. 65, 325-335.

Amezketa, E., 1999. Soil aggregate stability: a review. J. Sustain. Agric. 14, 83-151.

An, S.S., Mentler, A., Mayer, H., Blum, W.E., 2010. Soil aggregation, aggregate stability, organic carbon and nitrogen in different soil aggregate fractions under forest and shrub vegetation on the Loess Plateau, China. Catena 81, 226-233.

An, S.S., Cheng, Y., Huang, Y.M., Liu, D., 2013a. Effects of revegetation on soil microbial biomass, enzyme activities, and nutrient cycling on the Loess Plateau in China. Restor. Ecol. 21, 600-607.

An, S.S., Darboux, F., Cheng, M., 2013b. Revegetation as an efficient means of increasing soil aggregate stability on the Loess Plateau (China). Geoderma 209, 75-85.

Annabi, M., Le Bissonnais, Y., Le Villio-Poitrenaud, M., Houot, S., 2011. Improvement of soil aggregate stability by repeated applications of organic amendments to a cultivated silty loam soil. Agric. Ecosyst. Environ. 144, 382-389.

Ayoubi, S., Karchegani, P.M., Mosaddeghi, M.R., Honarjoo, N., 2012. Soil aggregation and organic carbon as affected by topography and land use change in western Iran. Soil Tillage Res. 121, 18-26.

Baldock, J.A., 2002. Interactions of organic materials and microorganisms with minerals in the stabilization of soil structure. In: Huang, P.M., Bollag, J.M., Senesi, N. (Eds.), Interactions Between Soil Particles and Microorganisms: Impact on the Terrestrial Ecosystem. Wiley \& Sons, Chichester (GB), pp. 85-131.

Bao, S.D., 2000. Soil and Agricultural Chemistry Analysis. China Agriculture Press, Beijing.

Barthes, B., Roose, E., 2002. Aggregate stability as an indicator of soil susceptibility to runoff and erosion; validation at several levels. Catena 47, 133-149.

Bissonnais, Y.L., Arrouays, D., 1997. Aggregate stability and assessment of soil crustability and erodibility: II. Application to humic loamy soils with various organic carbon contents. Eur. J. Soil Sci. 48, 39-48.

Cao, S., Chen, L., Yu, X., 2009. Impact of China's Grain for Green Project on the landscape of vulnerable arid and semi-arid agricultural regions: a case study in northern Shaanxi Province. J. Appl. Ecol. 46, 536-543.

Cerda, A., 1998. Soil aggregate stability under different Mediterranean vegetation types. Catena 32, 73-86.

Chaplot, V., Cooper, M., 2015. Soil aggregate stability to predict organic carbon outputs from soils. Geoderma 243, 205-213.

Cheng, M., Xiang, Y., Xue, Z., An, S., Darboux, F., 2015. Soil aggregation and intra-aggregate carbon fractions in relation to vegetation succession on the Loess Plateau, China. Catena 124, 77-84.

Deng, L., Liu, G.B., Shangguan, Z.P., 2014. Land-use conversion and changing soil carbon stocks in China's 'Grain-for-Green' Program: a synthesis. Glob. Chang. Biol. 20, 3544-3556.

Eisenhauer, N., et al., 2011. Plant diversity surpasses plant functional groups and plant productivity as driver of soil biota in the long term. PLoS One 6, e16055.

Erktan, A., et al., 2016. Increase in soil aggregate stability along a Mediterranean successional gradient in severely eroded gully bed ecosystems: combined effects of soil, root traits and plant community characteristics. Plant Soil 398, 121-137.

Freschet, G.T., et al., 2013. Linking litter decomposition of above-and below-ground organs to plant-soil feedbacks worldwide. J. Ecol. 101, 943-952.

Fu, B., Chen, L., 2000. Agricultural landscape spatial pattern analysis in the semi-arid hill area of the Loess Plateau, China. J. Arid Environ. 44, 291-303.

Greenway, D., 1987. Vegetation and slope stability. In: Anderson, M.G., Richards, K.S. (Eds.), Slope Stability: Geotechnical Engineering and Geomorphology.

Gyssels, G., Poesen, J., Bochet, E., Li, Y., 2005. Impact of plant roots on the resistance of soils to erosion by water: a review. Prog. Phys. Geogr. 29, 189-217.

Hortensius, D., Welling, R., 1996. International standardization of soil quality measurements. Commun. Soil Sci. Plant Anal. 27, 387-402.

Huang, Y.M., Liu, D., An, S.S., 2015. Effects of slope aspect on soil nitrogen and microbial properties in the Chinese Loess region. Catena 125, 135-145.

Jiao, J.Y., Zhang, Z.G., Bai, W.J., Jia, Y.F., Wang, N., 2012. Assessing the ecological success of restoration by afforestation on the Chinese Loess Plateau. Restor. Ecol. 20, 240-249.

Kalembasa, S.J., Jenkinson, D.S., 1973. A comparative study of titrimetric and gravimetric methods for the determination of organic carbon in soil. J. Sci. Food Agric. 24, 1085-1090.

Khormali, F., Ajami, M., Ayoubi, S., Srinivasarao, C., Wani, S., 2009. Role of deforestation and hillslope position on soil quality attributes of loess-derived soils in Golestan province, Iran. Agric. Ecosyst. Environ. 134, 178-189.

Kiem, R., Kandeler, E., 1997. Stabilization of aggregates by the microbial biomass as affected by soil texture and type. Appl. Soil Ecol. 5, 221-230.

Le Bissonnais, Y., 1996. Aggregate stability and assessment of soil crustability and erodibility: I. Theory and methodology. Eur. J. Soil Sci. 47, 425-437.

Le Bissonnais, Y., et al., 2007. Erodibility of Mediterranean vineyard soils: relevant aggregate stability methods and significant soil variables. Eur. J. Soil Sci. 58, 188-195.

Liu, Y., Tong, J., Li, X., 2005. Analysing the silt particles with the Malvern Mastersizer 2000. Water Conserv. Sci. Technol. Econ. 11, 329-331.

Lü, Y., et al., 2012. A policy-driven large scale ecological restoration: quantifying ecosystem services changes in the Loess Plateau of China. PLoS One 7, e31782.

Miller, R., Jastrow, J., 1990. Hierarchy of root and mycorrhizal fungal interactions with soil aggregation. Soil Biol. Biochem. 22, 579-584.

Nelson, D., Sommers, L.E., 1982. Methods of soil analysis. Part 2. Chemical and microbiological properties. Soil Science Society of America, Inc., Madison, Wisconsin USA

Oguike, P., Mbagwu, J., 2009. Variations in some physical properties and organic matter content of soils of coastal plain sand under different land use types. World J. Agric. Sci. 5, 63-69.

Pérès, G., et al., 2013. Mechanisms linking plant community properties to soil aggregate stability in an experimental grassland plant diversity gradient. Plant Soil 373, 285-299.

Ruiz-Colmenero, M., Bienes, R., Eldridge, D., Marques, M., 2013. Vegetation cover reduces erosion and enhances soil organic carbon in a vineyard in the central Spain. Catena 104, 153-160.

Six, J., Paustian, K., Elliott, E., Combrink, C., 2000. Soil structure and organic matter I Distribution of aggregate-size classes and aggregate-associated carbon. Soil Sci. Soc. Am. J. 64, 681-689.

Six, J., Bossuyt, H., Degryze, S., Denef, K., 2004. A history of research on the link between (micro) aggregates, soil biota, and soil organic matter dynamics. Soil Tillage Res. 79, 7-31.

Sparks, D.L., et al., 1996. Methods of Soil Analysis. Part 3-Chemical Methods. American Society of Agronomy-Soil Science Society of America, Madison, Wisconsin USA. 
Soil Survey Staff, 1999. Soil Taxonomy. USDA-NRCS, US Gov. Print. Office, Washington, DC.

Wang, Z.-J., Jiao, J.-Y., Su, Y., Chen, Y., 2014. The efficiency of large-scale afforestation with fish-scale pits for revegetation and soil erosion control in the steppe zone on the hill-gully Loess Plateau. Catena 115, 159-167.

Xu, M., Li, Q., Wilson, G., 2016. Degradation of soil physicochemical quality by ephemeral gully erosion on sloping cropland of the hilly Loess Plateau, China. Soil Tillage Res. 155, 9-18.

Yoder, R.E., 1936. A direct method of aggregate analysis of soils and a study of the physical nature of erosion losses. Agron. J. 28, 337-351.

Zeng, Q., Li, X., Dong, Y., An, S., Darboux, F., 2016. Soil and plant components ecological stoichiometry in four steppe communities in the Loess Plateau of China. Catena 147, 481-488.

Zeng, Q., An, S., Liu, Y., 2017. Soil bacterial community response to vegetation succession after fencing in the grassland of China. Sci. Total Environ. 609, 2-10.

Zhang, X., Miller, W., 1996. Physical and chemical crusting processes affecting runoff and erosion in furrows. Soil Sci. Soc. Am. J. 60, 860-865.

Zhao, G., Mu, X., Wen, Z., Wang, F., Gao, P., 2013. Soil erosion, conservation, and ecoenvironment changes in the loess plateau of China. Land Degrad. Dev. 24, 499-510.

Zhao, D., et al., 2017. Effect of vegetation type on microstructure of soil aggregates on the Loess Plateau, China. Agric. Ecosyst. Environ. 242, 1-8.

Zhou, H., Peng, X., Peth, S., Xiao, T., 2012. Effects of vegetation restoration on soil aggregate microstructure quantified with synchrotron-based micro-computed tomography. Soil Tillage Res. 124, 17-23.

Zhu, G.Y., Shangguan, Z.P., Deng, L., 2017. Soil aggregate stability and aggregate-associated carbon and nitrogen in natural restoration grassland and Chinese red pine plantation on the Loess Plateau. Catena 149, 253-260. 